\title{
Utilization of Natural Source Filters for the Removal of Contaminants from the Waste Water
}

\author{
Jeyakodi Moses, $\mathrm{J}^{*}$ \\ \{ jjmoses2k2@gmail.com\} \\ Associate Professor, Department of Applied Science, PSG College of Technology, Coimbatore \\ 641004, India.
}

\begin{abstract}
Water is one of the inevitable commodities in the day to day life of everyone, from the domestic applications to the industrial applications. As water easily dissolves almost everything directly or with the help of suitable chemicals, it is quite normal to use for the respective applications. After the chemical processing using water on the suitable materials, the residual solutions contains the contaminations that create pollution to the environment. Hence, nowadays it is made compulsory to treat the waste water to be suitable for mixing in the water bodies. Based on this context, in this work, it is decided to study on the waste water collected from the domestic washing machines and the textile chemical processing industries by utilizing the natural source filters. The results of which are in the convincing trend.
\end{abstract}

Keywords: Waste water, natural source filter, TDS, COD, BOD, environment friendly.

\section{Introduction}

The utilization of water is inevitable ranges from individual to societies; houses to industries in varied capacities. As water is used with the help of ingredients suitable for the application purposes, so the waste is also generated $(1,2)$. Nowadays, most of the houses are provided with washing machine useful for the cleansing of textile product materials in different capacities. After the cleansing process, the waste water from the machine is sent to the sewage or the water bodies as it is without any treatments (3-6). The outlet water from the washing machine if treated properly the water load could be considerably reduced. The important advantages of water recycling and /or reuse comprises reduction of the extraction of fresh water from the rivers and other water bodies, the good recharge in the ground water level, nutrient reclamations in the soil level, higher improvement in the quality of ground and surface water levels (7-10).

Waste water treatment is a process used to purify wastewater by removing the contaminants either from the domestic areas or from the different chemical processing industries so as to useful in different categories in the overall environment $(6,11-13)$. The present study is about the wastewater treatment.This treatment involves removing the contaminants of waste water with the help of natural sources.For this purpose, thenatural source materials like gravel, sand - red soil and charcoal are selected, purified and arranged as filterbeds through which the water to be treated is passed. The out put of this treatment gives good result suitable for the environment. 


\section{Materials and Methods}

\subsection{Materials}

The waste waters were collected as; 1 . From washing machine (10 houses, Peelamedu, Coimbatore, India), and 2. From the textile reactive dyeing industries (4 units, Tiruppur, Tamil Nadu, India). The natural sources selected for filters are; gravels, sands - red soil, and charcoal (from the commercial construction material supply shops, peelamedu, Coimbatore, Tamil Nadu). Twenty five empty 2.5 litre capacity plastic soft drink bottles to keep the filter materials in compact manner for the trials and the regular studies. All the trials and the regular studies were carried out in the Department of Applied Science, PSG College of Technology, Coimbatore, India.

\subsection{Methods}

\subsubsection{Natural source filter}

The natural filter was constructed from the three sources namely: gravel, sand - red soil, and charcoal. The natural sources were separately purified, washed, dried and sieved by the size of $4 \mathrm{~mm}, 100$ and 150 micrometer respectively $(2,4)$.

\subsection{1(a) Gravel}

Gravel comprises the un-consolidated fragments of rock with a considerable range of size in the particles. Filter gravel bed and sand grades for water treatment are used in single and multi-layer filtration systems. These products have highly homogeneous grain structures. Filter bed-gravel is an useful filter set-up due to the effective ability to have the precipitates comprising the contaminants. The filter gravel bed shall composes the required aspects of hardness with the rounded size instead of angular one in order to have the higher efficient results $(4,13)$.

\subsection{1(b) Sand - red soil}

In the water purification of waste water treatment, sand filters are considered in a effective manner. A sand bed The filter based on the sand bed is a type of steep filter in which the impurities are attracted with the reduced count of bacteria also as well removing maximum unwanted solid impurities. The important aspect in this kind of filter is the sand in varied grade types which may also comprises with some arranged layers of activated carbon so as to eradicate the unwanted tastes and odors $(6,8)$.

\subsection{1(c) Charcoal}

The important natural ingredient charcoal is considered as black light-weight residue comprising of carbon and other some ash contents collected by the removal of unwanted water and the volatile components. Charcoal in the purified form (activated charcoal) is applied for a varied aspects of medical purposes $(7,12,13)$.

\subsubsection{Waste water contaminants}

From the waste water, the important parameters, such as; $\mathrm{pH}$, turbidity, TDS. BOD, COD, and sulphates are analyzed $(6,8,9)$.

\subsection{2(a) $\mathrm{pH}$}

$\mathrm{pH}$ is known to be the negative of the logarithm base 10 of the activity of hydrogen ion. The chemical solution of $\mathrm{pH}$ lesser than seven is considered as acidic and those with $\mathrm{pH}$ more than seven is considered as basic. In general, the soft (pure) water contains near neutral pH (7). 


\subsection{2(b) Turbidity}

The term turbidity is taken as the haziness / cloudiness in a solution due to the higher numbers of the separate particulates which are normally invisible to the normal eyes. The turbidity usually considered as an important test for the quality water. The solutions may contains the presence of particles with different sizes as suspended solid matter. Very small suspended solid particles will lead the solutions to appear as turbid.

\subsection{2(c) TDS - Total dissolved solids}

Total dissolved solids is considered as the measure of the collected aspect of the organic and inorganic components in the solutions in ionized or molecular suspended manner. Normally the TDS are considered for the fresh water bodies.

\subsection{2(d) BOD - Biochemical oxygen demand}

BOD is known to be the amount of needed dissolved oxygen required by aerobic biological organisms so as to breaking down the organic components available in the water sample with noted temperature for the specific period. The value of BOD is generally revealed in $\mathrm{mg}$ of oxygen consumed per liter of the water sample for 5 days in incubation at the temperature of $20^{\circ} \mathrm{C}$.

\subsection{2(e) COD - Chemical oxygen demand}

COD is considered as an indication measure for the amount of oxygen consumed by the reactions in a known solution. COD is normally revealed by the mass of oxygen consumed

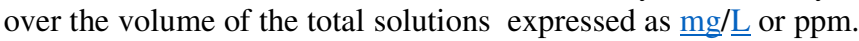

\subsection{2(f) Sulphate}

The common item possessed in water bodies as sulfates are not giving much toxic effects to plants and / or animals at the concentrations in the normal level. When the concentrations increases more than $750 \mathrm{mg} / \mathrm{L}$, it may cause a laxative effect in the human bodies. Sometimes. It may cause sever ill damages if the concentration increases in thousands $\mathrm{mg} / \mathrm{L}$. Sulfates are also toxic to cattles and the other animals when the concentration is prolonged. The sulfates are normally related to the ability to form their strong acids that enhances the $\mathrm{pH}$ towards the acidic side. Sulfate ions also are $\mathrm{n}$ Complexing and precipitation reactions are also possible with sulphate ions that will severely influencing in the solubility of metals and the corresponding substances.

\section{Results and Discussion}

\subsection{Arrangement of the filter layer in different combinations}

The natural source materials such as; Gravel, Charcoal, and Sand-Red soil are packed in a tight manner arranged in three layers. The listed filter materials are packed in a 2.5 liter capacity plastic container with the top opened and the bottom closed with the lid. A small hole ( $1 \mathrm{~mm}$ diameter) is provided in the lid to collect the filtered water.

3.1(a) First combination

The natural source materials are arranged in the following pattern of; 1. Top layer Gravel (30\%), 2. Middle layer - Charcoal (40\%), and 3. Bottom layer - Sand-Red soil (30\%) as seen in the following Figure 1. 


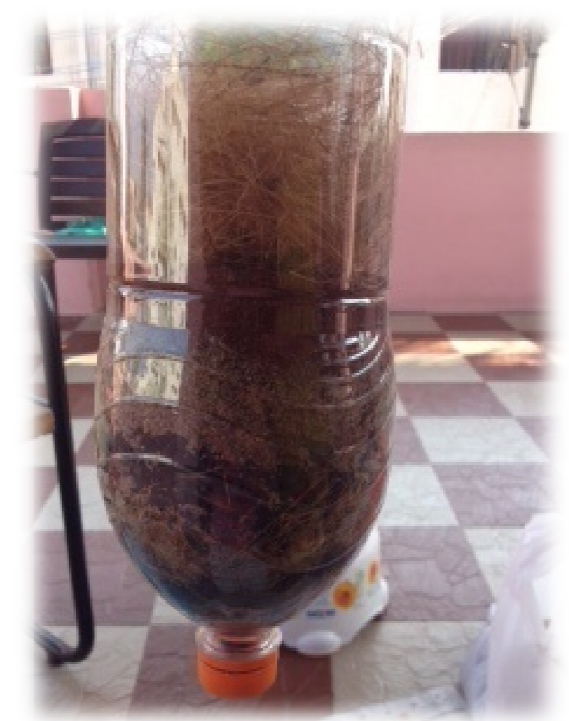

Figure 1. Filter layers: Gravel (30\%), Charcoal (30\%), and Sand-Red soil (40\%) 3.1(b) Second combination

The natural source materials are arranged in the following pattern of; 1. Top layer Gravel (30\%), 2. Middle layer - Sand-Red soil (40\%), and 3. Bottom layer - Charcoal (30\%) as seen in the following Figure 2.

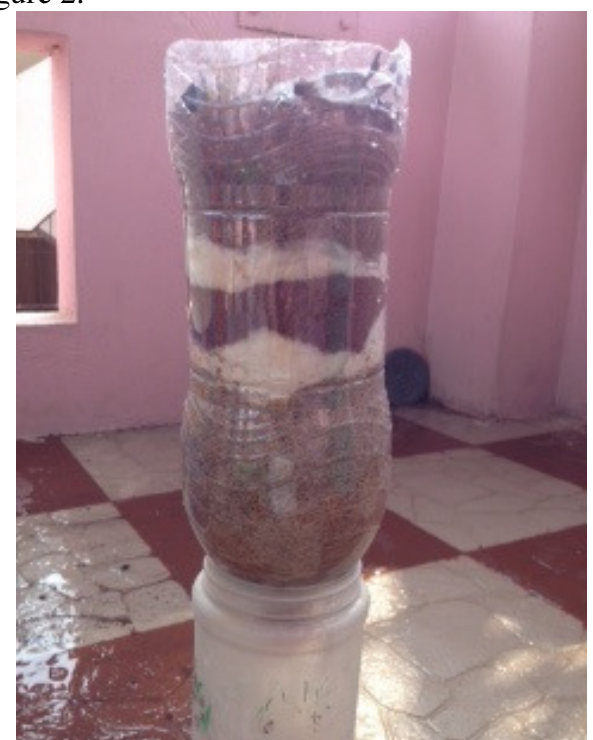

Figure 2. Filter layers: Gravel (30\%), Sand-Red Soil $(40 \%)$, and Charcoal (30\%) 


\subsection{Effect of the filter layer in removing the contaminants}

\section{2(a) First combination}

The waste water collected from different washing machine is analyzed separately; the average values of the individual parameters are presented here. Through the packed filter layer, the waste water collected from the washing machine is passed over it slowly. After, say five minutes the water in the filtered (purified) form is collected in a selected container. The collected water is analyzed for some basic parameters, and the results of which are given in the Table 1. From this table it is seen that before the treatment the waste water parameters ( $\mathrm{pH}$, turbidity, TDS, BOD, COD, Sulphate ) are in high values, however when the waste water from the washing machine is filtered through the first combination the contaminants based on the waste water parameters are reduced considerably. The treated waters are in the quality level near to the standard proposed by the pollution control board $(4,7,8)$.

Table 1. Effect of the filter layer by first combination

\begin{tabular}{|l|l|l|l|l|l|l|}
\hline $\begin{array}{l}\text { Water } \\
\text { Sample }\end{array}$ & pH & $\begin{array}{l}\text { Turbidity } \\
(\mathbf{N T U})\end{array}$ & $\begin{array}{l}\text { TDS } \\
(\mathbf{m g} / \mathbf{L})\end{array}$ & $\begin{array}{l}\text { BOD } \\
(\mathbf{m g} / \mathbf{L})\end{array}$ & $\begin{array}{l}\text { COD } \\
(\mathbf{m g} / \mathbf{L})\end{array}$ & $\begin{array}{l}\text { Sulphate } \\
(\mathbf{m g} / \mathbf{L})\end{array}$ \\
\hline $\begin{array}{l}\text { Before } \\
\text { Treatment }\end{array}$ & 10.28 & 84 & 688 & 465 & 2700 & 370 \\
\hline $\begin{array}{l}\text { After } \\
\text { Treatment }\end{array}$ & 7.94 & 0 & 163 & 138 & 180 & 66 \\
\hline
\end{tabular}

\section{2(b) Second combination}

Similar to the first combination, in the second combination also the waste water is passed to the natural source filter layer with different proportions. The data of which are shown in the Table 2. From this table it is observed that the waste water contamination is reduced considerably similar to what is observed in the first combination. However, compared to the results of the first combination filter, here the values are marginally high. This relative high values may be due to the difference in the proportion of charcoal which is more in the first combination compared to the second one. Charcoal is one of the valuable ingredient used for the waste water treatment due to the high surface value for the contact of adsorption for the contaminants in a effective way $(2,3,4)$.

Table 2. Effect of the filter layer by second combination

\begin{tabular}{|l|l|l|l|l|l|l|}
\hline $\begin{array}{l}\text { Water } \\
\text { Sample }\end{array}$ & $\mathbf{p H}$ & $\begin{array}{l}\text { Turbidity } \\
\text { (NTU) }\end{array}$ & $\begin{array}{l}\text { TDS } \\
(\mathbf{m g} / \mathbf{L})\end{array}$ & $\begin{array}{l}\text { BOD } \\
(\mathbf{m g} / \mathbf{L})\end{array}$ & $\begin{array}{l}\text { COD } \\
(\mathbf{m g} / \mathbf{L})\end{array}$ & $\begin{array}{l}\text { Sulphate } \\
(\mathbf{m g} / \mathbf{L})\end{array}$ \\
\hline $\begin{array}{l}\text { Before } \\
\text { Treatment }\end{array}$ & 9.32 & 84 & 688 & 465 & 2700 & 370 \\
\hline $\begin{array}{l}\text { After } \\
\text { Treatment }\end{array}$ & 8.20 & 0 & 184 & 140 & 204 & 78 \\
\hline
\end{tabular}

\subsection{Filter layer for the industrial contaminants 3.3(a) Filter layer combination}

Based on the effect of the filter layer in removing the contaminants from the washing machine, it is observed that the first combination gives the effective results. Hence for removing the industrial contaminants, the first combination is used (1. Top layer - Gravel (30\%), 2. Middle layer - Charcoal (40\%), and 3. Bottom layer - Sand-Red soil (30\%)). The 
arrangement is given in the Figure 3. The industrial contaminants are from the reactive dyeing unit where the coloration processes were performed on the cotton fiber materials.

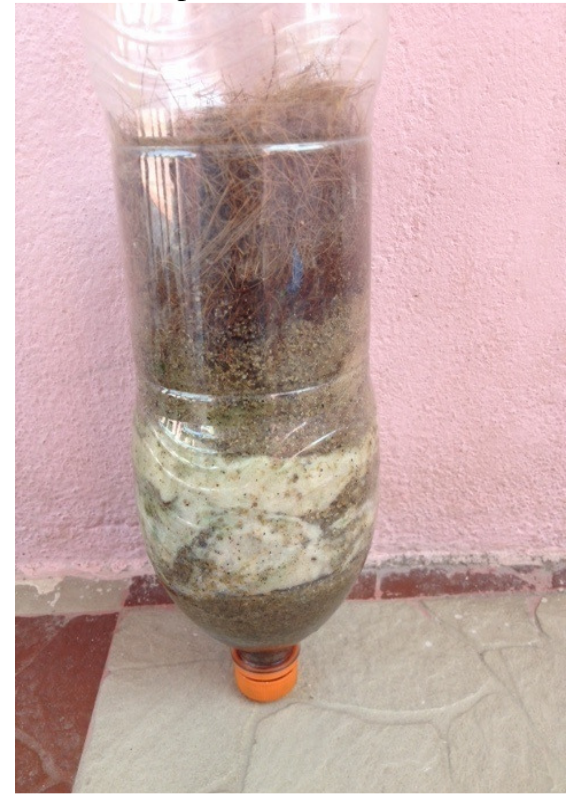

Figure 3. Filter layers for industrial contaminants

\section{3(b) Effect of filter layer in removing the industrial contaminants}

The waste water from the textile dyeing industry is passed to the natural source filter layer as done in the previous cases $(3.1 \& 3.2)$. The results obtained after this filtration are presented in the Table 3. In the table 3, it is evident that, the original contaminants (before treatment) from the industrial waste water is very high compared to the contaminants in the waste water of washing machine (Table $1 \&$ Table 2). This high contaminant values are due to the involvement of more chemicals in high concentration for achieving the efficient dyeing on the cotton fiber substrates. However, after the filtration (Figure 3) the contaminants values are considerably reduced similar to that of the one achieved for the washing machine waste waters. Compared to the values obtained after the filtration for the washing machine waste water (Figures $1 \& 2$; Tables $1 \& 2$ ) and the industrial waste water (Figure $3 \&$ Table 3), the former ones show considerably less values that are due to the involvement of very less chemicals (usually detergents only) $(4,7,8)$.

Table 3. Effect of the filter layer in removing the industrial contaminants

\begin{tabular}{|l|l|l|l|l|l|l|}
\hline $\begin{array}{l}\text { Water } \\
\text { Sample }\end{array}$ & pH & $\begin{array}{l}\text { Turbidity } \\
(\mathbf{N T U})\end{array}$ & $\begin{array}{l}\text { TDS } \\
(\mathbf{m g} / \mathbf{L}\}\end{array}$ & $\begin{array}{l}\text { BOD } \\
(\mathbf{m g} / \mathbf{L})\end{array}$ & $\begin{array}{l}\text { COD } \\
(\mathbf{m g} / \mathbf{L})\end{array}$ & $\begin{array}{l}\text { Sulphate } \\
(\mathbf{m g} / \mathbf{L})\end{array}$ \\
\hline $\begin{array}{l}\text { Before } \\
\text { Treatment }\end{array}$ & 10.86 & 145 & 1047 & 482 & 4095 & 848 \\
\hline $\begin{array}{l}\text { After } \\
\text { Treatment }\end{array}$ & 8.77 & 0 & 266 & 152 & 383 & 139 \\
\hline
\end{tabular}




\section{Conclusion}

From this research work, it is concluded that the natural source filter arranged by the order like; 1. Top layer - Gravel (30\%), 2. Middle layer - Charcoal (40\%), and 3. Bottom layer - Sand-Red soil $(30 \%)$ gives an efficient result in the removal of contaminants both from the domestic waste water come out from the washing machines and also from the textile dyeing industry effluents. The important pollutant parameters such as; $\mathrm{pH}$, turbidity, TDS, BOD, COD and sulphate levels are significantly reduced by utilizing this natural source filter combination.

\section{Acknowledgement}

We express our thanks to the Principal and the Management, PSG College of Technology; and the Head, Department of Applied Science, PSG College of Technology, Coimbatore 641004 for given all the supports and the facilities. The author expresses the deep sense of gratitude to Ms. G Suruthi, (14S024, B.Sc., Applied Science Student, 2014-2017 batch) for the effective help rendered for the completion of this research work.

\section{References}

[1] Peterson, H.G. Rural Drinking Water and Waterbourne Illness, In: Maintaining Drinking Water Quality, Lessons from the Prairies and Beyond, Proceedings of the Ninth National Water Conference on Drinking Water, Regina, SK, May 16-18, 2000, Ed: W. Roberston, Canadian Water and Wastewater, 2001.

[2] APHA, AWWA, WEF (2005) Standard methods for the examination of water and wastewater, 21st ed. Washington, DC, American Public Health Association, American Water Works Association and Water Environment Federation, 2005, pp. 7-15.

[3] Dullemont YJ et al. Removal of microorganisms by slow sand filtration. In: Gimbel R, Graham NJD, Collins MR, eds. Recent progress in slow sand and alternative biofiltration processes. London, IWA Publishing, 2006, pp. 12-20.

[4] Metcalf \& Eddy, Inc. Wastewater engineering: Treatment and reuse. New York, NY, McGraw Hill, 2003.

[5] Agarwal, A., Kimondo, J., Moreno, G., and Tinker, J. Water, Sanitation, Health - for all? Prospects for the International Drinking Water Supply and Sanitation Decade, 1981- 90. The International Institute for Environment and Development, 1983.

[6] Feachem, R., McGarry, M., and Mara, D. (eds.) Water, Wastes and Health in Hot Climates. John Wiley \& Sons: Chichester, UK, 1977.

[7] UNICEF, 'UNICEF strategies in Water and Environmental Sanitation' in Department for International Development (1998) Guidance Manual on Water Supply and Sanitation Programmes. WELL: London, UK, 1995.

[8] Callely, A.G., Treatment of Industrial Effluents; Haisted Press: New York, NY, 1976.

[9] C. Nivetha, D. S. Vijayan, R. Ravishanker et al., Use of Pennywort for nitrogen and phosphate removal from sewage, Materials Today: Proceedings, https://doi.org/10.1016/j.matpr.2020.05.215

[10] Norton-Brandao D., Scherrenberg S.M., van Lier J.B. Reclamation of used urban waters for irrigation purposes - a review of treatment technologies. J Environ Manag. 122, 2013, pp. 85-98.

[11] Choudr,.BS., Charabi, Y. Ahmed M. Health effects associated with wastewater treatment, Reuse and Disposal. Water Environ Res. 90(10), 2018, pp. 1759-76.

[12] S. M. S. S, D. S. Vijayan, M. Anand, M. Ajona, and T. Jarin, " Biodegradation of P-nitro phenol using a novel bacterium Achromobacter denitrifacians isolated from industrial effluent water ," Water Sci. Technol., vol. 00, no. 0, pp. 1-12, 2021, doi: 10.2166/wst.2021.354 
[13] Zhou,H., and Daniel W Smith. Advanced technologies in water and wastewater treatment, Canadian Journal of Civil Engineering, Vol 28 (S1)January 2001.

[14] Prabha, S. Lavanya, M. Surendar, and M. Neelamegam. "Experimental investigation of ecofriendly mortar using industrial wastes." Journal of Green Engineering 9.4 (2019): 626-637 